DOI: 10.1515/ausae-2017-0006

\title{
Assessment of nutrient content of tomato hybrids for processing
}

\author{
János ÁGOSTON, Péter TÓTH-HORGOSI, Tímea KISS, \\ Zsuzsanna TÓTHNÉ TASKOVICS
}

\author{
Pallas Athena University, Faculty of Horticulture and Rural Development, \\ Mészöly Gyula tér 1-3., Kecskemét - 6000, Hungary
}

\begin{abstract}
We have tested the refraction of 6 cultivars of open-field tomatoes. In our work, we have tested the nutritional values of tomato cultivars harvested at different times. Our aim was to answer the question as to which cultivar fulfils the requirements for processing under given circumstances. During harvest time, we also measured the ratio of yellow and red pigments. The trial was conducted in Kecskemét, Hungary, on the trial field of NAIK ZÖKO, in open-field conditions. The refraction measurement was done on weighted tomato, which was then ground to juice and then measured on a tabletop refractometer. The 6 tested cultivars Brix\% were measured at 5 different harvest dates, and then the average refraction of the harvest was analysed. The most suitable cultivar for processing was found to be Solerosso.
\end{abstract}

Keywords: tomato hybrids, cultivars, pigment ratio

\section{Introduction}

Among vegetables, tomato has a huge importance. The yearly production of the world regularly exceeds 150 million metric tons. A significant part of this production goes to processing. Processed tomatoes have certain advantages compared to fresh market, such as the pulping and the possibility to store it for longer periods without the deterioration of nutritional values (Szuvandzsiev et al., 2013). The world's tomato consumption was determined at $12 \mathrm{~kg}$ per person per year. There are significant differences between countries: for example, in tropical countries, the average consumption is $4 \mathrm{~kg}$ per person, while tomato consumption in Greece or in Italy reaches or even exceeds $25 \mathrm{~kg}$ per person. Hungary is around the world average: in the last one or two decades, it recorded 10-12 kg per person per year (Helyes et al., 2006). 
Tomato - like most of the vegetables - is not very high in calories. 100 gram of fresh tomato contains $92 \mathrm{~J}(22 \mathrm{Cal})$ of energy. The water content of the ripe fruit is around 93-96\%. Both the minerals and chemicals found in the tomato fruit are responsible for the favourable effect it causes in the human body's metabolism (Helyes et al., 2005). Water-soluble carbohydrates give the soluble dry matter (Brix\%), which is mostly made up of reducing sugars. The soluble dry matter of a ripe fruit is about $5-7.5 \%$ of the fresh weight. Most part of the dry matter is sugar and organic acids (Davies-Hobson, 1981), which are responsible for the taste of the fruit. The higher the average fruit size, the higher the water content and the lower the Brix\% (Varga, 2002). The ripe tomato fruit contains 93-96\% water, which dissolves carbohydrates, organic acids, minerals, vitamins, and pigments. This means that the soluble dry matter of a fresh tomato fluctuates between $4 \%$ and $7 \%$ $\left(\mathrm{Brix}^{\circ}\right)$. The dry matter content depends on the cultivar, the growing technology, and the environmental factors during the growing season (Helyes, 2007). In cherry tomatoes, soluble sugars gave $62 \%$ of the soluble dry matter, while determinate cultivars for processing had only $46 \%$ of the Brix ${ }^{\circ}$. In regard to sugar-acid ratio, cherry types gave significantly higher values (Helyes, 2007; Helyes et al., 2013).

The type of harvest (manual or machine) also influences the dry matter content of the raw material we supply for the processing company. In the case of manual harvest, the $\mathrm{Brix}^{\circ}$ is higher because the ratio of fully ripe fruit is higher (Jauregui et al., 1999). It is important to note that water quality also influences nutritional value and dry matter content (Doaris et al., 2008).

\section{Materials and methods}

\subsection{Trial conditions}

The trial was carried out on the NAIK ZÖKO's open field for vegetable trials. NAIK (Nemzeti Agrárkutatási és Innovációs Központ, English name: National Agricultural Research and Innovation Centre, acronym: NARIC) is an institute of national competence in Hungary. Processing companies' raw material need was supplied from tomato cultivars bred in Kecskemét till about the end of 1980s. By the turn of the millennium, processing capacities had been reduced just as production volumes, but using F1 hybrids had become general practice. The Hungarian Government wants to support the growth of the capacity of national processing companies, which requires high-yield cultivars with disease resistance and the ability for mechanical harvest. Breeders want to support the processing companies' research projects with new, early and mid-early cultivars with excellent parameters for processing. The work of Hungarian tomato breeders are praised by the fact that in Hungary tomatoes for processing are produced exclusively from their cultivars. Their latest cultivars are resistant to Xanthomonas vesicatoria - a 
bacterial disease of tomato. In their new projects, they are working on resistance to other diseases, creating doubled haploid lines, incorporating new sources of disease resistance, and applying new technologies under open field and glasshouse. The following determinate cultivars were used: Aragon F1, Solerosso F1, Mokka F1, Progress F1, Benito F1, and Albarossa F1. Plug production time was 5 weeks plugs were planted on the field on 8 May 2015 . The spacing was $120 \times 40 \times 40 \mathrm{~cm}$ (about 30,000 plants per hectare); plants were planted in twin rows. Irrigation and fertilization was carried out with drip tapes. Fertigation was carried out with $1.5 \%$ Yara Ferticare 10-5-26 once or twice a week, depending on the weather, with optimal water portions. Plant protection was carried out mechanically, row spacing was covered with agricultural fabric to keep them weed-free. Topping was an important plant manipulation technique for having as much fully ripe fruit as possible. It was carried out at a height that the top raceme could ripe at the designated harvest date. Harvest times are as follows: 1. 2015-08-17, 2. 2015-0825, 3. 2015-09-02, 4. 2015-09-15, and 5. 2015-09-22.

\subsection{Methods}

From each plant, 5 biologically ripe fruits were collected. They were ground to juice in a laboratory. For refraction, we used Hanna HI 96801 digital refractometer and for pigments we used Hunter D25. The refraction results were collected in temperature-compensation mode (nD20) and in non-compensated $(\mathrm{nD})$ mode. With the refraction, we were able to analyse the composition and density of liquids; so, this can be used in the food industry and environmental tests. Results can be viewed in Brix\%. Brix tests are used for water-soluble dry matter measurement - the refraction -, which in the case of tomato is made up mostly of sugars, but it is not an exact equivalent. Refraction, also known as Brix, is an important parameter in food processing. Refraction, or soluble dry matter (total soluble substrate, TSS), is made up of soluble sugars in the case of tomato - with good approximation, it can be considered equivalent. Brix expresses the sugar content of tomato: $1 \mathrm{Brix}^{\circ}$ (or $1 \mathrm{Brix} \%$ ) means there is $1 \mathrm{~g}$ of sugar in $100 \mathrm{~g}$ of tomato. Tomato values are between $4^{\circ}$ and $7^{\circ}-$ the higher the better. The sweetness of the fruit depends on the sugar content, but the allover taste depends on the ration of sugars and acids.

With the colour difference meter, we measured the light intensity of parts of the visual spectrum. 


\section{Results}

\subsection{Results of the refraction}

Fruits were weighted and ground to juice, and then refraction (sugar content) was measured with Hanna HI 96801 refractometer. Results are shown in Table 1 and in fig-s 1, 2.

Table 1. Sugar content of different tomato cultivars at 5 harvest dates

\begin{tabular}{|c|c|c|c|c|c|c|}
\hline $\begin{array}{c}\text { Harvest } \\
\text { time }\end{array}$ & $\begin{array}{c}\text { Aragon } \\
\text { F1 }\end{array}$ & $\begin{array}{c}\text { Solerosso } \\
\text { F1 }\end{array}$ & $\begin{array}{c}\text { Mokka } \\
\text { F1 }\end{array}$ & $\begin{array}{c}\text { Progress } \\
\text { F1 }\end{array}$ & $\begin{array}{c}\text { Benito } \\
\text { F1 }\end{array}$ & $\begin{array}{c}\text { Albarossa } \\
\text { F1 }\end{array}$ \\
\hline 2015.08 .17 & 6.98 & 6.95 & 6.33 & 7.07 & 6.04 & 6.57 \\
\hline 2015.08 .25 & 6.7 & 6.55 & 6.25 & 6.6 & 6.05 & 6.0 \\
\hline 2015.09 .02 & 4.93 & 5.75 & 5.25 & 5.75 & 5.35 & 5.55 \\
\hline 2015.09 .15 & 4.8 & 5.85 & 5.35 & 5.55 & 5.05 & 5.4 \\
\hline 2015.09 .22 & 4.5 & 4.5 & 5.15 & 5.15 & 5.55 & 5.25 \\
\hline Mean & $\mathbf{5 . 5 8}$ & $\mathbf{6 . 1 1}$ & $\mathbf{5 . 6 7}$ & $\mathbf{6 . 0 2}$ & $\mathbf{5 . 6 1}$ & $\mathbf{5 . 7 5}$ \\
\hline
\end{tabular}

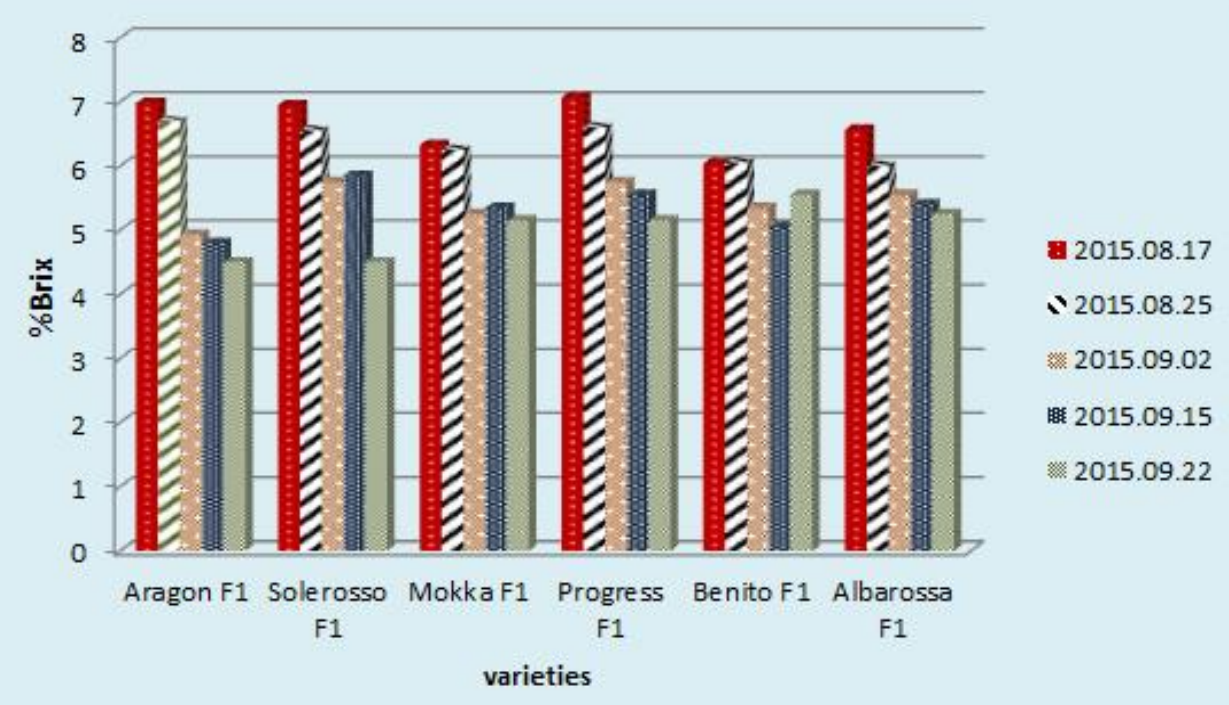

Figure 1. Dry matter content of different tomato cultivars by harvest date 


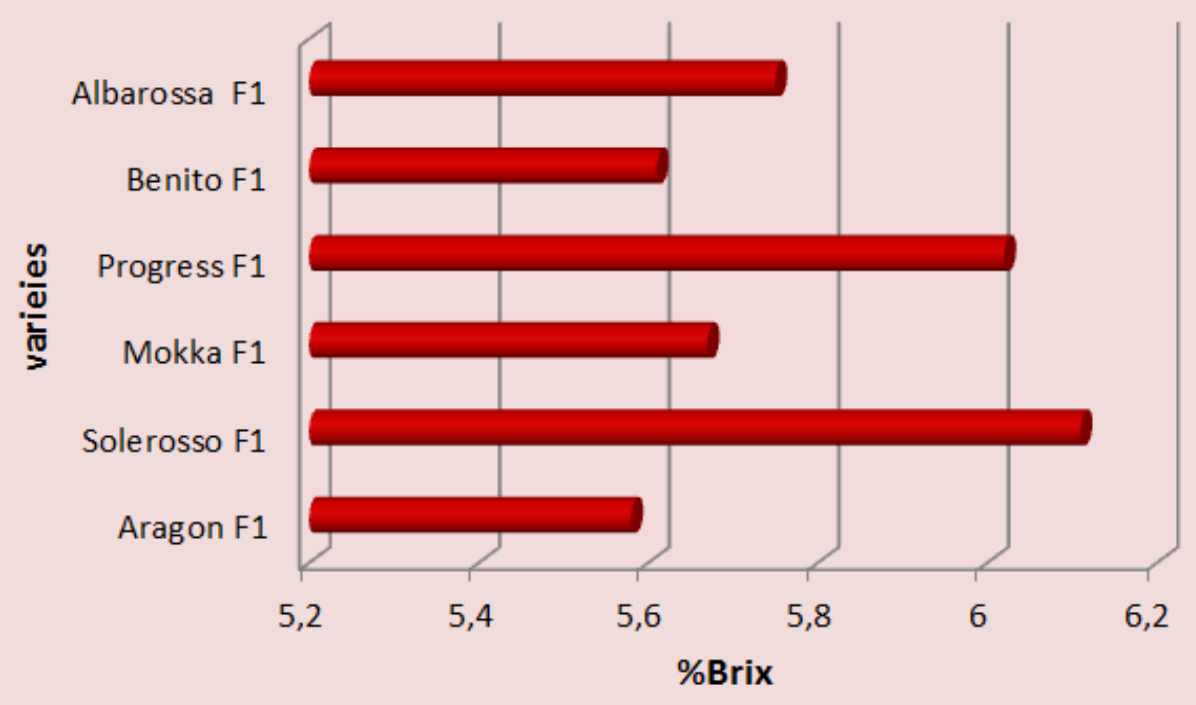

Figure 2. Graphic representation of mean Brix \% of different tomato cultivars

Tomatoes for processing should have at least $4.5 \%$ Brix. Fruits for fresh market should have Brix between 3.5 and 5.5. Cultivars in the trial have the following results:

Aragon F1: This cultivar had the lowest Brix\% in our trial. Although it had $6.7 \%$ at the second assessment, it was the lowest at the last 3 assessments.

Solerosso F1: It gave steadily over $6 \%$ for the first 2 assessments and had values near to $6 \%$ on later assessments.

Mokka F1: It had over $6 \%$ for the first 2 assessment dates but it gave a little bit over $5 \%$ for the last 3 times.

Progress F1: It had the highest refraction on $17^{\text {th }}$ of August with $7.07 \%$ but results show a steady decreasing tendency, which reduced the season's average. Even this was enough for it to be the second best in our trial.

Benito F1: It gave fluctuating results; the $3^{\text {rd }}$ and $4^{\text {th }}$ assessments gave unexpectedly low values. Even if the last result was better, the season average was $5.61 \%$.

Albarossa F1: This variety had a slow but steady decrease of sugar content throughout the assessment dates. Even so this was the $3^{\text {rd }}$ best in the trial with $5.75 \%$. 


\subsection{Colour measurement}

For the first 3 harvests, we measured the red-yellow pigment ratio of the varieties with Hunter D25 spectrophotometer. The visual assessment resulted in well-coloured, intensive red fruits even at the September harvest. Results were in compliance with the expectations for processing.

\section{Discussion}

Water-soluble dry matter content is highly influenced by the cultivar and the harvest time. The means of Brix show a steady decreasing trend from mid-August to mid-September.

Cultivars have significant differences, but still, the decreasing of Brix values is prominent. Our trial is good for grouping these tomatoes into excellent, intermediate, and low Brix cultivars. These tomatoes cannot be categorized by one Brix measurement - obviously, reliability could be increased with more repetitions and more frequent harvest times.

Harvest time is crucial - as our results show: at the first 2 harvest times, sugar content decreases.

\section{References}

[1] Davies. J. N., Hobson. G. E. (1981), The constituents of tomato fruit - the influence of environment, nutrition, and genotype. CRC Critical Reviews in Food Science and Nutrition 15, 205-280.

[2] Doaris, M., Ehret, D. L., Papadopoulos, A. P. (2008), Tomato (Solanum lycopersicum) health components: from the seed to the consumer. Phytochemisrty Reviews 7, 231-250.

[3] Helyes, L., Varga, Gy., Lugasi, A. (2005), A fajta szerepe a paradicsom (Lycopersicon lycoprsicum (L.) Karsten) fontosabb beltartalmi összetevőinek alakulására különböző termesztési módok esetén. Hajtatás Korai Termesztés XXXVI (4), 27-31.

[4] Helyes, L. (2007), A Paradicsom (Lycopersicon lycopersicum) (L.) KARSEN) termésképzödésére ható abiotikius és biotikus tényezök értékelése különös tekintettel a beltartalmi összetevőkre. MTA doktori értekezés. Gödöllő.

[5] Helyes, L., Dimény, J., Pék, Z., Lugasi, A. (2006), Effect of the variety and growing methods as well as cultivation conditions on ingredient of tomato (Lycopersicon lycopersicum (L.) KARSTEN) fruit. Acta Horticulturae 712, 511-516.

[6] Helyes, L., Neményi, A., Pék, Z., Berki, M., Daood, H. G. (2013), Effect of variety and water supply on phytochemical (phenolics and carotenoids) content and composition of processing tomato. Acta Horticulturae 971, 93-98.

[7] Jauregui, J. I., Lumbreras, M., Chavarri, M. J., Macua, J. I. (1999), Dry weight and brix degree correlation in different varieties of tomatoes intended for industrial processing. Acta Horticulturae 487, 425-430. 
[8] Szuvandzsiev, P., Daood, H. G., Neményi, A., Pék, Z. (2013), Az ipari paradicsom fontosabb fitonutrienseinek meghatározása látható- és közeli infravörös spektroszkópiával. LV. Georgikon Napok, 92-100.

[9] Varga, Gy. (2002), Az öntözés hatása egyes zöldségnövények termésének minőségére. Gödöllő. 